\title{
VALIDITAS PERANGKAT PEMBELAJARAN FISIKA BERBASIS MODEL GENERATIF BERBANTUAN LABORATORIUM VIRTUAL
}

\author{
Shinta Mutiara Dewi ${ }^{*}$, Gunawan ${ }^{2}$, Susilawati², Ahmad Harjono \\ ${ }^{1}$ Program Studi Magister Pendidikan IPA, Universitas Mataram \\ ${ }^{2}$ Program Studi Pendidikan Fisika, Universitas Mataram \\ *Email: shintamutiaradewi@gmail.com
}

DOI: http://dx.doi.org/10.29303/jpft.v5i1.1175

\begin{abstract}
The purpose of this study is to determine the validity of a learning tools based generative model with virtual laboratory. This type of research is Research \& Development refers to the 4-D model which consists of four stages of development, namely define, design, develop and disseminate. Learning tools developed in the form of syllabus, RPP, LKPD, and evaluation instruments. This paper only focused on the process of testing the validation of the contents and constructs of the learning tool. Validation has been carried out by experts using a validity test instrument in the form of a questionnaire. Validity test for syllabus, lesson plan, student worksheet and evaluation instruments get results with valid categories. Based on the results and discussion of the research it can be concluded that this learning tool is feasible to be used in physics learning.
\end{abstract}

Keywords : Generative Learning, Learning Tools, Validity, Virtual Laboratory

\section{PENDAHULUAN}

Kurikulum 2013 merupakan salah satu produk pengembangan dan penyempurnaan kurikulum di Indonesia yang menekankan keseimbangan antara kompetensi pengetahuan, sikap, dan keterampilan. Perangkat pembelajaran memiliki peran sebagai penunjang pelaksanaan pembelajaran dan harus mampu mengoptimalkan peran guru dan siswa dengan mengkondisikan suasana belajar lebih baik, menyenangkan, dan tepat sasaran (Juniantari, 2017).

Penguasaan konsep dalam pembelajaran fisika sangat penting untuk siswa. Penyebab rendahnya penguasaan konsep siswa adalah kurangnya pemahaman guru tentang tuntutan evaluasi konsep (Sholikhan, 2017). Salah satu upaya yang dilakukan untuk mengasah penguasaan konsep siswa adalah melalui pembelajaran dengan model generatif. Penelitian oleh Maknun (2015) menyatakan bahwa model pembelajaran generatif memberikan dampak yang lebih baik terhadap peningkatan penguasaan konsep fisika. Model generatif dapat membantu siswa untuk mengeksplorasi pengetahuan baru (Sugiana et al. 2016). Model generatif memberikan kesempatan kepada setiap siswa untuk mengutarakan konsepsinya dengan disertai argumentasi. Basaffar mengungkapkan bahwa penggunaan model generatif menumbuhkan sikap positif siswa dalam berinteraksi satu sama lain. Hal ini akan membiasakan siswa untuk mengemukakan pendapat dan mengembangkan ide-ide kreatif mereka.

Kurikulum yang digunakan sebelumnya, sisi kreativitas siswa kurang dikembangkan. Mengelola pembelajaran yang bermuara pada kreativitas siswa penting dilakukan sesuai dengan harapan kurikulum 2013 (Juniantari, 2017). Kreativitas dapat dikembangkan dengan mengkondisikan siswa untuk aktif terlibat langsung selama proses pembelajaran (Wyse \& Ferrari, 2015).

Materi pelajaran yang dikembangkan dalam perangkat pembelajaran ini adalah hukum gravitasi Newton yang merupakan materi dengan konsep yang abstrak dan sulit untuk divisualisasikan secara nyata. Kondisi ini 
berdampak pada rendahnya penguasaan konsep siswa (Gunawan et al. 2017). Solusi yang ditawarkan oleh peneliti adalah dengan menggunakan bantuan laboratorium virtual, sehingga konsep materi dapat tersampaikan sesuai dengan tuntutan tujuan pembelajaran. Pembelajaran dengan laboratorium virtual meningkatkan penguasaan konsep fisika siswa (Dewi et al. 2016; Kusdiastuti et al. 2016)

Kompetensi dasar keterampilan yang mewajibkan siswa harus melakukan percobaan yang berhubungan dengan pembuktian hukum gravitasi Newton dan hukum Kepler. Namun, tidak semua percobaan dapat dilakukan secara nyata di laboratorium, bukan karena tidak tersedianya alat laboratorium, tetapi karakteristik percobaan yang melibatkan proses dan konsep-konsep yang abstrak. Salah satu solusi alternatif terkait masalah tersebut yaitu dengan memanfaatkan laboratorium virtual, sehingga siswa dapat mengamati fenomena yang seringkali sulit untuk dijelaskan secara tertulis (Gunawan, 2015). Laboratorium virtual bukan untuk menggantikan laboratorium riil, tetapi berperan sebagai alternatif untuk melakukan percobaan secara virtual yang sulit digunakan dengan laboratorium nyata (Gunawan et al. 2017). Penelitian oleh Tawil \& Dahlan (2017) menyimpulkan bahwa pembelajaran berbasis simulasi komputer dapat meningkatkan penguasaan konsep dan kreativitas siswa.

Berdasarkan uraian di atas, maka tujuan umum penelitian ini adalah untuk menghasilkan perangkat pembelajaran fisika berbasis model generatif berbantuan laboratorium virtual untuk meningkatkan penguasaan konsep dan kreativitas siswa yang layak digunakan dalam pembelajaran.

\section{METODE PENELITIAN}

Jenis penelitian ini adalah penelitian dan pengembangan (Research and
Development) dengan menggunakan model 4-D yang terdiri dari 4 tahap pengembangan yaitu define, design, develop dan disseminate (Thiagarajan \& Semmel, 1974). Penelitian ini dibatasi sampai tahap develop, yang meliputi uji validitas. Data validitas perangkat pembelajaran divalidasi oleh validator ahli yang mengkaji dan menilai aspek isi dan kegiatan pembelajaran yang merupakan validitas konstruk (Opitz et al. 2017). Teknik analisis data menggunakan persamaan (1):

$$
\mathrm{V}=\frac{\text { rata-rata nilai validitas pakar }}{\text { skor maksimal }}
$$

Selain menilai secara kuantitatif, validator juga menilai secara kualitatif dari kualitas perangkat pembelajaran. Berdasarkan nilai $\mathrm{V}$ yang diperoleh, ditetapkan kriteria validitas (Ratumanan \& Laurens, 2011) pada Tabel 1 berikut.

Tabel 1. Kriteria Hasil Penilaian Validitas

\begin{tabular}{ll}
\hline Nilai rata-rata & \multicolumn{1}{c}{ Kategori } \\
\hline $4.2 \geq \mathrm{SV} \leq 5.0$ & Sangat Valid \\
$3.4 \geq \mathrm{SV} \leq 4.2$ & Valid \\
$2.6 \geq \mathrm{SV} \leq 3.4$ & Cukup Valid \\
$1.8 \geq \mathrm{SV} \leq 2.6$ & Kurang Valid \\
$1.0 \geq \mathrm{SV} \leq 1.8$ & Sangat Kurang Valid \\
\hline
\end{tabular}

Perangkat pembelajaran dalam penelitian ini minimal harus mencapai kategori valid untuk bisa digunakan dalam pembelajaran. Saran dan masukan dari para validator ahli sebagai dasar utama dalam mengoreksi dan revisi perangkat pembelajaran, sehingga didapatkan produk yang layak dan dapat digunakan (Nerita et al. 2018).

\section{HASIL DAN PEMBAHASAN}

Proses pengembangan perangkat ini diawali dari tahap define yaitu analisis awal, pada kegiatan ini dilakukan analisis kurikulum untuk menentukan masalah dasar yang diperlukan dalam pengembangan perangkat pembelajaran, analisis siswa, materi, tugas dan konsep. 
Berdasarkan hasil observasi dan wawancara yang telah dilakukan dengan guru SMA di kota Mataram, informasi yang didapat adalah dalam proses pembelajaran siswa menggunakan buku paket dan LKPD yang merupakan produk orang lain, sehingga cenderung tidak sesuai dengan kondisi dan kebutuhan pembelajaran. Temuan lain yaitu tidak memanfaatkan media virtual sebagai alat peraga untuk menerangkan konsep yang abstrak sehingga pembelajaran tidak sampai pada tujuan yang diinginkan. Guru tidak memperhatikan jenis model pembelajaran yang digunakan selama proses pembelajaran. Pemilihan model pembelajaran sangat penting dan disesesuaikan dengan karakteristik materi pelajaran (Rochmad, 2012).

Tabel 2. Hasil Validasi Perangkat Pembelajaran

\begin{tabular}{|c|c|c|c|c|c|c|c|}
\hline \multirow[t]{2}{*}{ No } & \multirow{2}{*}{$\begin{array}{l}\text { Perangkat } \\
\text { Pembelajaran }\end{array}$} & \multicolumn{3}{|c|}{ Rata-rata skor validator } & \multirow{2}{*}{ Jumlah } & \multirow{2}{*}{ Rata-rata } & \multirow{2}{*}{ Kategori } \\
\hline & & V1 & $\mathrm{V} 2$ & V3 & & & \\
\hline 1. & Silabus & 4.00 & 4.00 & 4.00 & 12.00 & 4.00 & Valid \\
\hline 2. & RPP & 4.00 & 4.07 & 4.03 & 12.10 & 4.03 & Valid \\
\hline 3. & LKPD & 4.04 & 4.08 & 4.04 & 12.16 & 4.05 & Valid \\
\hline 4. & $\begin{array}{l}\text { Instrumen tes } \\
\text { penguasaan konsep }\end{array}$ & 4.00 & 4.00 & 4.00 & 12.00 & 4.00 & Valid \\
\hline 5. & $\begin{array}{l}\text { Instrumen tes } \\
\text { kreativitas }\end{array}$ & 4.16 & 4.00 & 4.00 & 12.16 & 4.05 & Valid \\
\hline
\end{tabular}

Setelah melewati tahap analisis awal, kemudian dilanjutkan pada tahap design, dalam hal ini peneliti merancang silabus, RPP, LKPD, instrumen tes penguasaan konsep dan kreativitas yang mengacu pada model generatif berbantuan laboratorium virtual. Model pembelajaran ini menurut peneliti dapat menjadi salah satu solusi permasalahan dari hasil observasi tersebut. Hasil rancangan perangkat pembelajaran ini kemudian dijadikan draf perangkat pembelajaran.

Tahap selanjutnya yaitu develop, kegiatan pertama melakukan validasi untuk mengetahui kevalidan perangkat pembelajaran, kegiatan kedua yaitu uji coba skala terbatas untuk mengetahui kepraktisan dari perangkat pembelajaran, kemudian kegiatan ketiga uji coba skala luas setelah perangkat dikatakan valid dan praktis. Tahap ini bertujuan untuk mengetahui: (1) draf perangkat pembelajaran yang telah disusun valid atau tidak berdasarkan pertimbangan para ahli yaitu dosen pembimbing dan validator, (2) perangkat pembelajaran yang valid tersebut praktis digunakan di sekolah tempat penelitian, (3) perangkat yang valid dan praktis dapat mencapai hasil sesuai dengan tujuan yang telah ditetapkan yaitu pembelajaran yang efektif.

Berikut hasil pada tahap pengembangan. Namun, pada pembahasan ini akan diuraikan tujuan yang pertama saja yaitu hasil analisis validitas dan revisi oleh validator ahli untuk menilai kelayakan perangkat pembelajaran. Hasil validasi terhadap silabus, RPP, LKPD, instrumen tes penguasaan konsep dan kreativitas secara keseluruhan dengan kategori valid. Berikut disajikan rangkuman hasil validasi oleh validator ahli pada Tabel 2 .

Tabel 2 menyimpulkan bahwa nilai validitas isi dan konstruk perangkat pembelajaran yang dikembangkan dalam penelitian ini memenuhi kategori valid karena rata-rata skor validitasnya berada pada interval 3,4 $\leq S \mathrm{~V} \leq 4,2$.

Masukan dan saran dari validator ahli, pada silabus dan RPP yaitu harus disesuaikan antara kegiatan guru dengan kegiatan siswa yang mengarahkan kepada ketercapaian indikator kreativitas. Penilaian terhadap LKPD dengan model generatif berbantuan laboratorium virtual yang 
didasarkan pada indikator kreativitas. LKPD yang dikembangkan ditulis dengan mengunakan bahasa yang baik dan mudah dimengerti oleh pembaca. Bahasa yang baik adalah bahasa yang sesuai dengan keperluan komunikasi dalam pembelajaran (Afza, 2016). LKPD disajikan secara menarik dilengkapi dengan gambar dan keteranganketerangannya serta isi yang menggambarkan sesuatu sesuai dengan ide penulis.

Instrumen tes penguasaan konsep dinilai berdasarkan pada kesesuaian soal dengan tingkatan ranah kognitif C1-C6. Beberapa revisi dari validator yaitu kesesuaian struktur kalimat dengan perintah soal pada ranah kognitif C5 dan C6. Sedangkan revisi pada tes kreativitas yaitu kesesuaian alokasi waktu dengan bobot soal. Syarat soal yang baik setidaknya harus melalui dua langkah, yaitu: validitas dan reliabilitas tes. Analisis dilakukan melalui uji validitas, reliabilitas, tingkat kesukaran, dan daya pembeda pada butir soal yang dikembangkan (Sugiyono, 2017).

Setelah dilakukan uji validitas pada butir soal sesuai dengan kategori yang telah ditetapkan, maka hasil akhir yang diperoleh adalah soal-soal yang memenuhi kategori valid, reliabel, dan daya pembeda yang mengacu pada indikator pencapaian kompetensi ranah kognitif C1-C6 dan indikator-indikator kreativitas.

\section{PENUTUP}

Berdasarkan hasil penelitian dapat disimpulkan bahwa proses validasi perangkat yang dikembangkan memenuhi validasi isi dan konstruk. Hal ini berarti bahwa perangkat pembelajaran yang dikembangkan layak dan dapat digunakan dalam pembelajaran fisika SMA.

\section{UCAPAN TERIMAKASIH}

Terimakasih kepada Kementerian Riset dan Pendidikan Tinggi yang telah membiayai penelitian ini melalui hibah tesis magister tahun 2019.

\section{REFERENSI}

Afza, A. 2016. Pengembangan Perangkat Pembelajaran Biologi Berorientasi Model Problem Based Learning (PBL) bermuatan Karakter. Jurnal BioConcetta. 2(1): 128-141.

Basaffar, F.M. 2017. The Effect of Implementing Some Generative Learning Model Strategies in Teaching Reading Comprehension. International Journal of English Language Education. 5(1): 42-53.

Dewi, S.M., Harjono, A., \& Gunawan. 2016. Pengaruh model pembelajaran berbasis masalah berbantuan simulasi virtual terhadap penguasaan konsep dan kreativitas fisika siswa SMAN 2 Mataram. Jurnal Pendidikan Fisika dan Teknologi, 2(3), 123-128.

Gunawan. 2015. Model Pembelajaran Sains Berbasis ICT. Mataram: FKIP UNRAM.

Gunawan, G., Harjono, A., Sahidu, H., \& Herayanti, L. 2017. Virtual Laboratory of Electricity Concept to Improve Prospective Physics Teachers' Creativity. Jurnal Pendidikan Fisika Indonesia. 13(2): 102-111.

Gunawan, G., Harjono, A., Sahidu, H., \& Herayanti, L. 2017. Virtual Laboratory to Improve Students' Problem-Solving Skills on Electricity Concept. Jurnal Pendidikan IPA Indonesia. 6(2): 257-264.

Juniantari, M. Pengembangan Perangkat Pembelajaran Matematika Berorientasi Pendidikan Karakter dengan Model Treffinger Bagi Siswa SMA. Journal of Education Technology. 1(2): 71-76.

Kusdiastuti, M., Harjono, A., Sahidu, H., \& Gunawan. 2016. Pengaruh Model 
Pembelajaran Inkuiri Berbantuan Laboratorium Virtual Terhadap Penguasaan Konsep Fisika Peserta Didik. Jurnal pendidikan Fisika dan Teknologi. 2(3), 116-122.

Maknun, J. 2015. The Implementation of Generative Learning Model on Physics Lesson to Increase Mastery Concepts and Generic Science Skills of Vocational Students. American Journal of Educational Research. 3(6), 742-748.

Nerita S., Hartati Y, S., Maizeli, A., \& Afza A. 2018. Validitas Handout Berbasis Penemuan Terbimbing Pada Perkuliahan Evaluasi Proses dan Hasil Belajar Biologi. Jurnal Penelitian Pendidikan IPA. 4(2), 5155.

Opitz, S. T., Neumann, Bernholt, S., \& Harms, U. 2017. How do students understand energy in biology, chemistry, and physics? Development and validation of an assessment instrument. Eurasia Journal of Mathematics Science and Technology Education, 13(7), 30193042

Ratumanan, G.T., \& Laurens, T. 2011. Evaluasi Hasil Belajar Tingkat Satuan Pendidikan. Surabaya: Unesa University Press.

Rochmad. 2012. Desain Model Pengembangan Perangkat Pembelajaran Matematika. Jurnal Keano. 3(1): 59-72.

Sholikhan. 2017. Understanding Concepts through Inquiry Learning Strategy. IOSR Journal of Research \& Method in Education (IOSR-JRME). 7(1): 97-102.

Sugiana, I.N., Harjono, A., Sahidu, H., \& Gunawan. 2016. Pengaruh Model Pembelajaran Generatif Berbantuan Media Laboratorium Virtual Terhadap Penguasaan Konsep Fisika Siswa pada Materi Impuls dan Momentum. Jurnal pendidikan Fisika dan Teknologi, 2(2), 61-65.
Sugiyono. 2017. Metodologi Penelitian Kuantitatif, Kualitatif, dan $R \& D$. Bandung: Alfabeta.

Tawil, M., \& Dahlan, A. 2017. Developing Students' Creativity through Computer Simulation Based Learning in Quantum Physics L earning. International Journal of Environmental and Science Education. 12(8): 1829-1845.

Thiagarajan, S., Semmel, D. S \& Semmel, M. I. 1974. Instructional Development for Training Teachers of Expectional Children. Minneapolis, Minnesota: Leadership Training Institute/Special Education, University of Minnesota.

Wyse, D., \& Ferrari, A. 2015. Creativity and Education: Comparing the National Curricula of the States of the European Union and the United Kingdom. British Educational Research Journal. 41(1), 30-47. 